\title{
Amendments of 2020 to the Russian Constitution as an Update to Its Symbolic and Identity Programme
}

\author{
Jakub Sadowski ${ }^{1}$ D
}

Accepted: 19 November 2020 / Published online: 15 February 2021

(c) The Author(s) 2021

\begin{abstract}
In the renewed Russian Fundamental Law, in addition to a number of provisions introducing changes to the political system, there are also statements of programmatic importance, as well as several provisions with symbolic and identity function. In this article these provisions are subject to functional and semiotic-cultural analysis. Particular emphasis has been placed on legally irrelevant content transmitted by the new regulations, on their semantic connections with the content of the preamble and on their cultural context. The research procedure carried out allows us to state that, compared with the 1993 text, the Russian Constitution in its current version participates to a much greater extent in the complex system of transmission of symbolic content, as well as the narratives that contribute to social memory, cultural and historical identity. In doing so, it goes beyond its genre limitations, opening the basic text to the functions assigned to the preamble. In the fragments I have analysed in the paper there are undoubtedly functional and genre disturbances, and with them changes the mode of semiosis of the legal text, both in its normative and programmatic form. Renewed Constitution is the case in which a legal text, by its very nature designing the possible future world, does so through ideas about the past.
\end{abstract}

Keywords Russia $\cdot$ Constitution $\cdot$ Amendment $\cdot$ Identity $\cdot$ Preamble $\cdot$ Semantics

On July 4th 2020 the political and legal system of the Russian Federation underwent a number of modifications. On that day, the new version of the country's Constitution was officially published in the government's Rossiiskaya Gazeta-with a number of amendments adopted in a recent referendum [6]. As a result of the introducing of the package of these amendments, some regulations concerning the competences

This article is made open access with funding support from the Jagiellonian University under the Excellence Initiative - Research University programme (the Priority Research Area Heritage).

Jakub Sadowski

jakub.sadowski@uj.edu.pl

1 Institute of Eastern Slavonic Studies, Jagiellonian University, Kraków, Poland 
of both chambers of the Russian Parliament and the Constitutional Court have changed; the State Council of Russian Federation, which has been operating until now on the basis of the Russian President's decree of 2000 [8], has become the constitutional body. Undoubtedly of the utmost importance in current politics are the new regulations on the candidacy of the country's President office. As a result, Vladimir Putin, after the end of his third presidential term, will be entitled to run for two more.

It is worth noting that in the renewed Fundamental Law, in addition to a number of regulations introducing changes to the political system, there are also statements of programmatic importance, as well as several provisions with symbolic function. Already at the beginning of this paper it is necessary to stress their importance for the set of meanings transmitted by the Russian Constitution, as well as their significance for the ontology of this legal text. It should also be noted at the very outset that their legal relevance is not obvious.

\section{Sub-genres of Constitutional Text}

The analysis of the symbolic components of the constitutional text necessarily requires looking beyond its legal dimension. Obviously, such a text belongs to different semiotic fields or, in the categories proposed by Lotman [13: 123-130], to different semiospheres: from the hermetic and specialized legal one to the general semiosphere of the language of a particular culture. Through its intertextual, functional and other links, the constitution is a unit of various aggregates of texts. First of all, it belongs to an aggregate of legal texts, understood as a set of all valid texts of a particular legal system [14: 117, 143, 162; 22: 24], being the central place in its structure and the highest element in its hierarchy. Secondly, depending on its own status in the semiosphere of the community in which it operates, it may belong to an aggregate of its symbolic texts. The place and status of a constitution in the internal hierarchy of this aggregate depends on a number of factors, e.g. on the status of statutory law in the cultural system of the community, or on the complex of meanings co-created by the constitution itself (e.g. historical narratives about its adoption). Finally, the constitution may belong to another, specific text aggregate, which is in fact an amalgam of the previous two. Let us call it a symbolic-legal aggregate. A constitutional text can co-create and organize it by the functions it performs in the legal system and in the symbolic field, as well as by indicating the legal canon of symbolic texts (that is, by the definition of state symbolism).

Due to its function in the political and legal system, the constitution features its own specific content, structure and language. Function, content, structure and language make the constitutional text the only representative of its class in the aggregate of the legal text. They make it recognizable in terms of a number of parameters and impossible to confuse with any other unit of the aggregate. Therefore, the constitution can be considered not only in terms of the highest hierarchical unit of the text aggregate, but also in terms of a specific genre.

The genre specificity of the constitutional text has managed to develop its own instruments for organising the content not only of the legal aggregate, but also of 
the symbolic-legal one. A typical and flagship instrument in this respect is the preamble. As long as the Constitution begins with a preamble, the status of this component is different in the various aggregates indicated above. Depending on the methodological approach, the preambles (similarly to other legal acts' introductions) may either not be included in the aggregate of the legal texts at all (as Matczak does [14: $158]$ ), or indicate its belonging to non-normative components of the aggregate. It is impossible to assign to the preamble such a function in the set of symbolic texts that would remain the same in the cultures of all communities that have a constitution with a solemn introduction. However, it can certainly be stated that the majority of known preambles of adopted (not imposed) constitutions co-create the identity fabric of the semiosphere and create structures of credibility of the fundamental lawits social and cultural legitimacy.

Within the broadly understood democratic tradition, the text of the fundamental law acquires legitimacy by meeting the requirements of the collectively shared ideas about the institution of its adoption. To put it simply and at a very columnist level: a constitution is formally legitimate when it is properly adopted. We are obviously implying here formal legitimacy, which, although essential in a democratic system, is only one of the possible instruments for the community to recognize a text as its own, binding and authoritative.

It is precisely for this purpose that symbolic and narrative strategies are used, aimed at or resulting in a link between the text of the constitution and those resources of the semiosphere that are responsible for shaping identity narratives. Clearly, the language of the regulatory provisions, which are the essential function of the legal text, does not favour such strategies. Therefore, the constitution as a genre provides for the possibility of a sub-genre of the preamble within it. This sub-genre operates in a language that allows a direct appeal to collective identities, using structures that are not descriptive but narrative. And which allows a community whose political and legal functioning is governed by the constitution to 'recognize itself' in its text. This very aspect allows Addis to consider the constitutional preambles as "narratives of peoplehood' [5], looking at them as at an attempt to create, on the one hand, structures that are recognized as "self-definitions" of the people' [5: 140] and, on the other hand, a kind of autobiography of a political nation [5: 139].

The preamble, therefore, although it forms an integral part of the constitution, is based on different sign structures than the basic text. Thus, it operates in a different language and determines a semiosis of a different shape than that of the basic text. While the function of the semiosis of the basic text is to transmit the content of the legal norm, the semiosis of the preamble is conducted on two levels and performs two functions. At the first level, it appeals to identity constructs, socially objectivized and individually recognizable, giving the reader (on the condition, of course, that he or she belongs to the community of a given political nation) the tools to identify him/herself with the collective subject of the text. At the second one, it projects the identity message onto the legal component of the constitution, simultaneously inscribing the latter into the structures of the identity narration. The preamble therefore makes the basic text of the constitution not only regulate the life of the community, but also aspire to narrate about it. 
In the case of the presence of a narrativized introduction, the semiosis of the whole constitutional text is the result of a clash of two images of the world: one directed towards the past-and one directed towards the future. The 'vector of the past' is an obvious result of the presence of a component of the political nation's collective autobiography; the 'vector of the future' results from the fact thataccording to the Matczak's concept [14: 158-165] - the legal component of the constitution, because of its belonging to the legal text aggregate, is a part of the image of the postulated and possible world. It should be noted that in the texts of the statutory law, such a world is constructed by means of both regulatory and programmatic clauses. Due to the genre features of the constitution, the presence of the latter is noticeable and achieves a significant proportion in its text, determining the shape of the law to be made, as well as forming a vision of the community's development.

It is therefore a circumstance in which two images of the world, as well as two of its specific temporal vectors, are linked to constitutional sub-genres - the preamble and the basic text. A separate group of content (with a different degree of relevance in a system of legal, symbolic and identity references) is usually correlated with each of the sub-genres. Each has its stylistic and grammatical markers (such as the person of the grammatical subject). Each participates in the process of amalgamation of meanings transmitted by the text-and as such is responsible for a different model of semiosis [7: 147-167]. As a result of its different models, one and the same lexeme used in the preamble and in the basic text performs different functions and carries different meanings. Therefore, the two components of the constitutionthe preamble and the basic text-are usually autonomous from each other and do not build direct content links between themselves.

For these reasons, the case of the changes to the Constitution of the Russian Federation in 2020 is extremely interesting. One of the effects of the introduction of a number of amendments to the fundamental law has just become the establishment of direct links between its functionally different and linguistically autonomous components. Unlike the previous versions of the Russian Constitution of 1993, the current text includes content that interacts dynamically with the preamble in terms of semantics.

\section{Preamble of 1993: In Search of a New Identity}

The elaboration of the preamble of the Russian Constitution immediately after the break-up of the USSR was a difficult and responsible semiotic operation. As Addis notes, "the legitimacy of a constitutional order is its capacity to capture the essence of "we the people" [5: 177]. Meanwhile, the answer to the question about the essence of 'we the people' in 1993 was probably the least obvious in all modern Russian history. The point is that neither ethnic Russians nor representatives of other ethnicities living in the country developed mental tools to identify themselves with Russia as it was after the fall of the USSR. For several reasons.

First of all, despite its formation in 1922 from four formally independent states, in the semiosphere of Russian culture the Soviet Union had (and continues to have) the status of heir to the Russian Empire. From the point of view of Russian historical 
memory, tsarist Russia and the USSR constitute the same state at different stages of its development. However, at the time of the collapse of the Soviet Union, this memory did not "recognize" any state within the territory of the Russian Soviet Federative Socialist Republic. The map of post-Soviet Russia lacks certain points of reference-crucial for Russian cultural identity and for the associated symbolic geography. Representatives of Russian culture had to start defining their community in relation to space with Moscow and St. Petersburg, but without Minsk, Odessa, Crimea and, above all, without Kiev, which in Russian historical memory functions as the "mother of Russian cities".

Secondly, the specificity of Soviet domestic policy caused the inhabitants of the RSFSR to have a number of mental instruments to identify with the USSR as a whole-and much less to identify with their union republic. Let us put together some facts to illustrate this thesis. In the non-Russian republics, the Communist Party of the Soviet Union had formal organizational autonomy - with its own name, its republican Central Committee-and formal political autonomy, obviously limited to 'local issues' [2], or to the issue of 'adaptation' of the CPSU policy 'to local conditions' [3]. Similar autonomy was enjoyed by the republican executive bodies, by the structures of the Academy of Sciences and creative unions. Moreover, the RSFSR had a poorer official republican symbolism — unlike the other republics with their state anthems (introduced from the late 1940s onwards), Russia established its own only on the edge of the Soviet Union's collapse, having already declared its sovereignty. In contrast, the first two lines of the USSR national anthem ('Soyuz nerushimyy respublik svobodnykh/Splotila naveki Velikaya Rus'—'Great Russia has consolidated forever the unbreakable union of free republics') left no doubt that in official Soviet symbolic discourse [23] Russia and the USSR remain in a metonymical relationship.

Furthermore, Russia has been a multi-ethnic country since the beginning of its history-and the USSR was its successor also in this respect. With the constant pressure of ethnically based centrifugal forces, which only just contributed to the disintegration of the Soviet state and which did not disappeared with its break-up, finding a proposal for a common identity denominator for all the ethnicities of Russia was of unquestionable value. It is precisely as a proposal for such a denominator that the text of the 1993 preamble should be considered. A proposal not 'to capture the essence of "we the people", but to create mental structures of credibility and symbolic legitimacy of the state - of the own one, but which is difficult to recognize as own. Here are some key points from it, numbered for the purposes of this paper:

[1] We, the multinational people of the Russian Federation,

[2] united by a common fate on our land, [...]

[3] preserving the historically established state unity, [...]

[4] revering the memory of ancestors who have conveyed to us the love for the Fatherland, belief in the good and justice, [..]

[5] adopt the CONSTITUTION OF THE RUSSIAN FEDERATION [19].

Already the first line, which is the core of the political nation's self-definition, indicates multinationalism as a category of identity narrative. Logically, in the 
phrase 'we, the multinational people' the adjective used might seem unnecessaryafter all, 'multinational people of the Russian Federation' are still 'simply people' of that country. However, the presence of the attribute of 'multinational' redirects the recipient's attention from the community itself to a certain feature of it, shaping the specific perspective of the identity narratives contained in the further components of the preamble. This is a very inclusive perspective, helping the legitimate recipient of the message (a Russian citizen) to 'find himself' in the proposed common denominator. The process of such 'finding oneself' is also supported by the very general nature of the subsequent proposed components of this denominator. They do not contain any specific historical references, replaced by foggy 'common fate'. Nor are there any direct historical-geographical or territorial references, replaced by no less vague 'historically established state unity'. The axiological canon presented in the self-description of the nation is reduced to universal values-'good and justice' - and to inclusive 'love for the Fatherland'.

It should be noted, however, that despite a number of highly abstract notions and the lack of specific references to the past, the excerpts from the preamble cited prove that the narrative is directed precisely towards the past. Verses 2-4 provide the recipient with elements that refer to individually remembered but socially objectivized historical narratives related to Russian statehood. They favour the mental 'synchronization' of the recipient with the proposed common denominator. This is done, for example, by referring to the 'common fate' and 'the memory of ancestors'. It is also worth noting that there is the same relationship between 'preserving the historically established state unity' and 'preserving the state unity' as between 'we, the multinational people' and 'we, the people' of Russia. The attribute used here has both an identity and narrative function. Pointing out the historical determinants of the unity of the state is intended to strengthen the mental structures of credibility of both the text of the Constitution and the political system it implies. According to Matczak's concept [14: 158-165] it should be added that the function of attributes referring to the past is to strengthen the collective legitimacy of the world postulated by the Constitution.

\section{Amendments of 2020}

We will now look at those provisions of the main text of the Constitution which, as a result of the 2020 amendments, are beginning to interfere with the preamble shaped in this way. This is the case with two articles in Chapter 3 of the Fundamental Law-'The Federal Structure': the newly introduced Article 67.1 and Article 68 in the new version.

The first paragraph of Article 67.1 is, at first sight, of a regulatory nature and defines a group of obligations of the Russian Federation as a subject of international law. However, its true function and links with the content of the preamble emerge in relation to the following paragraphs - so we will deal with it a little further. Now let us quote paragraph 2, where the connection with the text of the preamble leaves no doubt: 
The Russian Federation, united by a thousand years of history, preserving the memory of ancestors who handed us ideals and faith in God, as well as succession in the development of the Russian state, recognizes the historically established state unity [6].

It is clear that the above wording is linked to lines 2, 3 and 4 of the preamble. It appeals to their content, makes itself structurally similar to them and re-codes them. The codification mechanism is linked to several factors. The first two are the grammar of the sentence and the content of the subject. The subject is no longer 'we, the people', but 'the Russian Federation'. Of course, in the language of modern legislation it would be difficult to construct a sentence based on a collective first-person subject, and only constitutional preambles are eligible for exceptions in this respect. It should be noted, however, that in the sentence quoted one can still find a clear trace of 'we, the people' - in the phrase 'ancestors who handed us ideals and faith in God'. Finally, it should be stressed that thanks to the modification of content and grammar, what in the preamble was a category of collective self-description takes on a programmatic nature in the main text as the basis of the state system.

The re-coding of verses $2-4$ of the preamble is carried out also thanks to semantic interaction of their content with the content of paragraph 2. First of all, it is worth noting an important detail: while in the introduction to the Constitution the collective subject 'preserves the historically established state unity', in Article 67.1 the Russian Federation 'recognizes the historically established state unity'. This apparent informational redundancy makes it necessary to pay attention to the verb which differentiates the mentioned formulations. While in 1993 the word 'preserve' was used to build the postulate of identifying with Russia in its present form, in 2020 the verb 'recognize' proves that Russia itself (as the third-person subject of the sentence in paragraph 2) has no longer problems with recognizing its borders. 'State unity' here is no longer a blurred postulate, but a value and a fact objectivized in collective identity. Moreover, as such, it is taking on a new identity meaning after 2014, i.e. after the annexation of Crimea (as stated in resolution of Parliamentary Assembly of the Council of Europe [17]) or the Crimea's reunification with Russia (as presented in treaty between the Russian Federation and the Republic of Crimea-[20]).

There is one more observation to make: 'succession', 'unity', 'state', 'God' in connection with 'a thousand years of history' are a very specific set of keywords. They refer not only to the history of the Russian state, not only to the history of Christianity in the Russian lands, but also to Russia's most important historiosophical idea-Moscow, third Rome. It was with it that a complex of ideas about Russia as the only country of legitimate Christianity was formed, as the successor of the imperial status of Rome and Byzantium, as well as about the Russians as a godbearing people. And it is this idea, forming a mythologeme (a figure that condenses mythological content in linguistic and textual units-[18]) inscribed in the above keywords, that provides the content of the paragraph 2 with a link to a series of historical narratives, obvious to every participant in Russian culture [12, 21: 21-59; 16: 63-68].

Let us now look at paragraph 3: 
The Russian Federation respects the memory of the defenders of the Fatherland and protects the historical truth. It is not allowed to diminish the significance of the heroism of the people in defending the Fatherland [6].

Like the paragraph analysed a bit above, this one also results in some transformation of the meanings contained in the preamble. Both line 4 and paragraph 3 refer to the same interrelated categories: 'memory' and 'love of the fatherland'. In the preamble, however, they are supplemented by the category of 'ancestors', in the main text by 'defenders'. The inclusive programme of the preamble prefers here a high degree of abstraction-when decoding verse 4 it is possible to activate both individual and collective memory content. Paragraph 3, replacing 'ancestors' with 'defenders of the Fatherland', introduces into the text of the Constitution a mythologem that is easily recognizable both in Russian culture and in official state discourse. The narratives activated together with the concept of 'defence of the Fatherland' (nowadays connected mainly with the memory of the Great Patriotic War, i.e. direct Soviet involvement in the theatre of World War II) favour the reception of the text in identity and emotional terms. Thus, in terms more typical of the collective selfdescription than of the legal provisions defining the state system. It is worth adding that the declaration on the protection of 'historical truth' and the specific constitutional prohibition of diminishing of 'the significance of the heroism of the people in defending the Fatherland' give the political system the function of protecting an identity programme based on the mythologeme of defence.

It is already clear that paragraphs 2 and 3 of Article 67.1 have an identity function in the basic text of the Russian Constitution. It can also be seen that by referring to the categories of history and memory, to the elements of axiology, as well as to the community-recognisable historical narratives, this text-formally called to describe the present world and to postulate the future one-participates in the transmission of representations of the past. Having found this tendency we can already analyse the content of paragraph 1:

The Russian Federation is the legal successor of the USSR on its territory, as well as the legal successor (legal continuator) of the USSR in respect of membership in international organizations, their bodies, participation in international treaties, as well as in respect of obligations and assets of the USSR outside the territory of the Russian Federation stipulated by international treaties [6].

The legal relevance of this provision should, of course, be subject to legal analysis, not to semiotic one. Even so, however, it should take into account the fact that the constitutional confirmation of Russia's status as a successor to the Soviet Union 27 years after the adoption of the Constitution and 29 years after the Belovezha Accords, must be based on other than purely legal grounds. Meanwhile, in paragraphs 2 and 3 we have already recognized the identity function and found a number of hidden historical narratives. This entitles us to look much deeper than just at the regulatory layer of paragraph 1 . The first thing that needs to be said when examining the provision it contains is that the proper name 'USSR', hitherto completely absent from the Fundamental Law, gets now included in its text. Having found its 
way into the Constitution, it is placed with the name 'Russian Federation' in a specific relationship.

This relationship arises from the terms used to describe the Russian Federation. Russia is called the 'legal successor' of the Soviet Union, and then the term is equated in brackets with the phrase 'legal continuator'. In the Russian text of the Constitution, these terms are expressed respectively by the nouns 'pravopreemnik' and 'pravoprodolzhatel'. Both are compounds formed by a combination of the lexeme 'pravo' ('law'), 'preemnik' ('sucessor') and 'prodolzhatel' ('continuator'). However, the resulting units of meaning are not equivalent, neither in legal nor in general language. 'Pravopreemnik' has a conventional legal meaning, fixed also in normative dictionaries of the Russian language (in the contemporary dictionary by Kuznetsov it is referred to as 'the person who inherits, who has been granted all rights and obligations of another person, organisation' [4]). However, the word 'pravoprodolzhatel'' is not to be found in normative or even specialized dictionaries. Instead, there is a noun 'prodolzhatel',-Ushakov's dictionary defines its meaning as 'a man who continues and develops the work of his predecessor' [1]. The same dictionary, illustrating the entry with the phrase 'comrade Stalin is a genius continuator of Lenin's cause', testifies to the possibility of a wide use of the noun in ideological discourse. 'Pravoprodolzhatel'' is, in turn, an endemic term that appears in legal, political and journalistic discourse in one single context in which Russia is presented as the continuator of the statehood of the Soviet Union and the Russian Empire. ${ }^{1}$ In the legal text, the noun 'pravoprodolzhatel'" so used appears for the first time in the Federal Law of 1999 'On the State Policy of the Russian Federation towards Compatriots Abroad', where we can read:

The Russian Federation is the legal successor and legal continuator of the

Russian State, the Russian Republic, the Russian Soviet Federative Socialist

Republic (RSFSR) and the Union of Soviet Socialist Republics (USSR) [9].

In the above formulation, however, the terms that are of interest to us are not equal-Russia is at the same time both a successor and continuator of Russian statehood in all its modern and contemporary incarnations (the RSFSR acts here as a separate subject of international law from the period before the establishment of the USSR). Moreover, the validity of the use of these expressions towards Russia in the light of international law is today the subject of scholarly analyses $[10,11]$. However, as used in the Constitution, these formulations determine the performative function of paragraph 1 of Article 67-thanks to them it becomes a proclamation of contemporary Russia as an inheritor of the USSR, while giving the recipients the exclusive right to mental participation in the heritage of this country.

However, taking into account the specificity of paragraphs 2 and 3 of Article 67.1 of the Constitution, which we have already stated, it must be acknowledged that the appearance of as many as two terms, which are semantically directly linked to the category of continuity, and contextually to the category of statehood, makes it possible to consider the whole article as one in which the legal function gives way for

\footnotetext{
1 My thanks to Prof. Dorota Szumska for the linguistic consultation.
} 
the identity one. All the more so because it is opened by the mention of the USSR, a proper name that is key in the identity field of the semiosphere of contemporary Russian culture, and because the following paragraphs transmit culturally and socially relevant narratives and mythologies.

Such an interpretation of Article 67 is only seemingly contradicted by the content of paragraph 4, which is formally of a programmatic nature:

Children are a top priority of Russian state policy. The state creates conditions that facilitate the comprehensive spiritual, moral, intellectual and physical development of children, nurturing in them patriotism, civic awareness and respect for elders. The state, ensuring the priority of family upbringing, assumes the responsibilities of parents in relation to children deprived of parental care [6].

However, there is no functional contradiction between the identity function of the first three paragraphs, which are semantically linked to the past, and the above provision, which concerns new generations and is therefore somewhat forward-looking. The identity programme contained in the article clearly corresponds to the provisions of the preamble, developing and complementing the content that is behind the concept of 'we the people'. As Addis notes, this concept, by its very nature, 'refers not only to the historical people that authored it, but to subsequent generations as co-authors' [5: 142] and needs therefore mechanisms that make it relevant to the imagined future recipients of the Constitution and shape its 'transtemporal authorship' [5: 142; 15]. This is why the introduction of the programme declaration concerning children (moreover, just after the set of historical identity reference points) constitutes in fact a development of the presented identity scheme. All the more so because among the listed attributes of upbringing are: spirituality, morality, patriotism, civic awareness and respect for elders - that is to say, categories which directly appeal to the programme of the preamble, extended by Article 67.

In this article, the semiosis of identity message is based on provisions of a formally programmatic nature and on the wording of paragraph 1 , which, as we have stated, has a performative function rather than a programmatic or normative one. However, it is enough to look at Article 68, as updated by the amendment, to get an understanding of the possibility of transmitting identity content based on provisions of a formally normative nature. Let us compare paragraph 1 of this article in the 1993 and 2020 versions respectively:

The Russian language shall be a state language on the whole territory of the Russian Federation [19].

The Russian language shall be a state language on the whole territory of the Russian Federation as the language of the state-forming nation that is a part of the multinational union of equal peoples of the Russian Federation [6]. 
We can see that the provision on the status of the Russian language has been extended to include a legally irrelevant and, on top of that, troublesome component in terms of formal logic. In the case of a normative provision, the wording 'Russian language' would seem sufficiently precise. After all, the Russian literary language is codified, perfectly distinguishable from other languages, and there is no other language that aspires to the name 'Russian'. However, the legislator considered it appropriate to introduce a specifying appositive into the sentence, suggesting precisely the existence of 'other Russian languages'.2 The expression 'Russian as...' has, by the way, the status of a linguistic usus: in the official language of the education sphere there is 'Russian as a native language' and 'Russian as a foreign language' (sometimes jokingly called 'Russian as non-Russian'). As a result of interference in the text of the constitutional provision, the logical analysis of paragraph 1 of Article 68 leads to the conclusion that there may be a Russian language other than 'the language of the state-forming nation'. So, if on Russian territory a foreigner applies in 'Russian as a foreign language' he has learned to a Russian official who speaks 'Russian as the language of the state-forming nation', are both speaking in the state language of the Russian Federation?

However, the logical implications of the amendment text do not seem to affect the legal norm contained in paragraph 1 of Article 68, and the paradoxes formulated above are unlikely to impact the interpretation of this provision. In a normative sense, therefore, the amendment adds nothing to the text of the paragraph, and its functions - as in the cases discussed earlier — should be sought elsewhere. Once again, attention should be drawn to the implicitly present, socially objectivized, narrativized and positively valued historical ideas - this time concerning the genesis of the Russian state, the unification of the Russian lands, the territorial expansion of Russia, and finally, concerning the Russian state as a 'multinational union of equal peoples'. It should be noted, moreover, that the constitutional expression of such an idea is consistent with the similar expressions known from the text of the USSR anthem (both from the 'Stalinist' and 'Brezhnev's' version of the song), as well as of the anthem of contemporary Russia. In the Soviet one, which starts from words on the role of Great Russia in the consolidation of the state, in the chorus the fatherland is described as 'druzhby narodov nadezhnyy oplot' ('a reliable stronghold of friendship among peoples'). In the official song of the Russian Federation, an analogous passage contains the term 'bratskikh narodov soyuz vekovoy' ('the centuries-old union of the brotherly peoples').

\section{Legal Norm as a Symbol Carrier}

The above circumstances make the legal norm contained in the text of the Constitution a servant of the historical and identity message. In Article 68 we are dealing with a case in which a mythologeme is 'attached' to a pre-existing norm, oroverwritten on it. In turn, in Article 67.1, added in its entirety to the text of the

\footnotetext{
${ }^{2}$ My thanks to Dr. Krzysztof Ozga for the linguistic consultation.
} 
Fundamental Law, a number of programmatic provisions have been created in a form that enables the transmission of identity content.

As we have already stated above, it is reasonable for the Constitution, which is a unit of an aggregate of legal texts, but also of a symbolic aggregate, to transmit symbolic and identity content. A semiotic analysis cannot show why the Russian executive, which initiated the amendments to the Constitution, seeing the need to supplement its identity programme, has not decided on a conventional step and has not proposed changes to the preamble. The answer to this question may remain in the purely political sphere. However, the effect of the legislative strategy undertaken is that the basic text of the Fundamental Law takes over the function of transmission of the content usually reserved for the preamble.

Therefore, while the 1993 preamble text may seem too abstract to become an element that constructs the structures of credibility and symbolic legitimacy of the Constitution, a number of elements that could strengthen it (in the form of historical and worldview references) have found their place in the basic component of the law.

Such a strategy partly repeats the one that accompanied the change of state symbolism at the turn of 2000 and 2001. Then 'Patriotic Song' by Mikhail Glinka, accepted as the anthem of the RSFSR in 1990, gave way to the current state official song. Its text, referring to the content of the USSR anthem and written by its co-creator, Sergei Mikhalkov, is performed to the famous Soviet melody, composed by Alexandr Aleksandrov. The introduction of the anthem, which refers to the Soviet tradition, did not prevent the presence in the official symbolic space of those elements which refer to the tradition of the Russian Empire - that is, the white-blue-red flag and emblem which combines the heraldic signs of the Roman (and Byzantine) Empire and the Grand Duchy of Moscow. The official Russian symbolic strategy therefore makes use of elements referring to the imperial Russia as well as to the Soviet Union (which was initially supposed to be the antithesis of its predecessor). Similarly, the symbolic components of the Fundamental Law now link the references to God (and thus - in the reality of Russian culture - to the Orthodox tradition) and to the USSR. In addition, the preamble of the 1993 Constitution remains unchanged as an element of the symbolic-legal sphere.

It is therefore time to state that, compared with the 1993 text, the Russian Constitution in its current version participates to a much greater extent in the complex system of transmission of symbolic content, as well as the narratives that contribute to social memory, cultural and historical identity. In doing so, it goes beyond its genre limitations, opening the basic text to the functions assigned to the preamble. In the fragments we have analysed, there are undoubtedly functional and genre disturbances, and with them changes the mode of semiosis of the legal text, both in its normative and programmatic form. We are dealing with a case in which a legal text, by its very nature designing the possible future world, does so through ideas about the past.

Authors' contributions Not applicable.

Funding Not applicable.

Code Availability Not applicable. 


\section{Compliance with Ethical Standards}

Conflict of interest The authors declared that they have no conflict of interest.

Availability of Data and Material The material analysed is publicly available.

Open Access This article is licensed under a Creative Commons Attribution 4.0 International License, which permits use, sharing, adaptation, distribution and reproduction in any medium or format, as long as you give appropriate credit to the original author(s) and the source, provide a link to the Creative Commons licence, and indicate if changes were made. The images or other third party material in this article are included in the article's Creative Commons licence, unless indicated otherwise in a credit line to the material. If material is not included in the article's Creative Commons licence and your intended use is not permitted by statutory regulation or exceeds the permitted use, you will need to obtain permission directly from the copyright holder. To view a copy of this licence, visit http://creativecommons.org/licen ses/by/4.0/.

\section{References}

1. 1939. Prodolzhatel'. In Tolkovyy slovar' russkogo yazyka. Tom III. P-Ryashka. Ed. D. N. Ushakov. 922. Moskva: Gosudarstvennoe izdatel'stvo inostrannykh i natsional'nykh slovarey.

2. 1973. Kommunisticheskaya partiya Belorussii v rezolyutsiyakh i resheniyakh s''ezdov i plenumov TsK. T.1. 1918-1927. Minsk: Belarus'.

3. 1976. Komunistychna partiia Ukrainy v Rezoliutsiiakh i Rishenniakh Zizdiv, Konferentsii i Plenumiv TsK. T. 1. Kyiv: Politvydav Ukrainy.

4. 2008. Pravopreemnik. In Bol'shoy tolkovyy slovar' russkogo yazyka. Ed. S. A. Kuznetsov. 954. Sankt-Peterburg: Norint.

5. Addis, Adeno. 2018. Constitutional Preambles as Narratives of Peoplehood. ICL Journal 12 (2): 125-181.

6. Constitution of the Russian Federation as amended and approved by the All-Russian vote on July 1, 2020 [working translation] [Konstitutsiya Rossiyskoy Federatsii s izmeneniyami, odobrennymi v khode obshcherossiyskogo golosovaniya 1 iyulya 2020 goda]. https://rg.ru/2020/07/04/ konstituciya-site-dok.html. Accessed 1 Oct 2020.

7. Czerwiński, Maciej. 2015. Kultura. Dyskurs. Znak. Kraków: Wydawnictwo Uniwersytetu Jagiellońskiego.

8. Decree of the President of the Russian Federation No 1602 of September 1, 2000 'On the State Council of the Russian Federation' [Ukaz Prezidenta Rossiyskoy Federatsii ot 01.09.2000 g. № 1602 'O Gosudarstvennom sovete Rossiyskoy Federatsii']. http://www.kremlin.ru/acts/ bank/16037. Accessed 1 Oct 2020.

9. Federal Law of May 24, 1999 N 99-FZ 'On the State Policy of the Russian Federation towards Compatriots Abroad' [Federal'nyy zakon ot 24 maya 1999 g. N 99-FZ 'O gosudarstvennoy politike Rossiyskoy Federatsii v otnoshenii sootechestvennikov za rubezhom']. http://base.garan t.ru/12115694/. Accessed 1 Oct 2020.

10. Gavlo, YuN. 2000. Raspad SSSR i mezhdunarodno-pravovoy status Rossiyskoy Federatsii. Izvestiya Altayskogo gosudarstvennogo universitetaю 2: 065-070.

11. Kremnev, P.P. 2008. Kategoriya 'Rossiyskaya Federatsiya - gosudarstvo-prodolzhatel' SSSR: voprosy teorii i praktiki. Vestnik Moskovskogo universiteta. Seriya 11. Pravo 2: 3-22.

12. Lotman, Juri M., and Uspenskij, Boris A. 1984. Echoes of the notion 'Moscow as the third Rome' in Peter the Great's ideology. In The Semiotics of Russian Culture eds. Lotman, Juri M. and Uspenskij, Boris A., 53-67. Ann Arbor: Department of Slavic Languages and Literatures, University of Michigan.

13. Lotman, Yuri M. 1990. Universe of the Mind. A Semiotic Theory of Culture. London: I.B. Tauris \& Co., Ltd.

14. Matczak, Marcin. 2019. Imperium tekstu. Prawo jako postulowanie i urzeczywistnianie świata możliwego. Warszawa: Wydawnictwo Naukowe Scholar. 
15. Michelman, Frank I. 1998. Constitutional Authorship. In Constitutionalism: Philosophical Foundations, ed. Larry Alexander, 64-98. Cambridge: Cambridge University Press.

16. Przybył, Elżbieta. 1999. W cieniu Antychrysta: idee staroobrzędowców w XVII w. Kraków: Zakład Wydawniczy Nomos.

17. Resolution 1988 (2014). Recent developments in Ukraine: threats to the functioning of democratic institutions. https://pace.coe.int/en/files/20873/html. Accessed 1 Oct 2020.

18. Sadovskiy, Yakub. 2018. Kondensatsiya politicheskoy mifologii. Mifologema v tekstakh totalitarnogo yazyka. In Sovetskiy proekt. 1917-1930-e gg. Etapy i mekhanizmy realizatsii. Sbornik nauchnykh trudov, ed. YOleg Gorbachev et al., 137-147. Ekaterinburg: Izdatel'stvo Ural'skogo federal'nogo universiteta.

19. The Constitution of the Russian Federation [official English translation]. http://www.constituti on.ru/en/10003000-01.htm. Accessed 1 Oct 2020.

20. Treaty between the Russian Federation and the Republic of Crimea on the admission of the Republic of Crimea to the Russian Federation and the formation of new subjects within the Russian Federation [Dogovor mezhdu Rossiyskoy Federatsiey i Respublikoy Krym o prinyatii v Rossiyskuyu Federatsiyu Respubliki Krym i obrazovanii v sostave Rossiyskoy Federatsii novykh sub" 'ektov]. https://rg.ru/2014/03/18/krim-site-dok.html. Accessed 1 Oct 2020.

21. Uspenskij, Boris, and Victor Zhivov. 2012. Tsar and God: Semiotic Aspects of the Sacralization of the Monarch in Russia. In 'Tsar and God' And Other Essays in Ryssian Cultural Semiotics, ed. Boris Uspenskij and Victor Zhivov, 1-112. Boston: Academic Studies Press.

22. Zieliński, Maciej. 1972. Interpretacja jako proces dekodowania tekstu prawnego. Poznań: Wydawnictwo Naukowe UAM.

23. Zoloteeva, T.S. 2013. Gosudarstvennyy gimn kak zhanr politicheskogo diskursa. Politicheskaya lingvistika 1 (43): 133-143.

Publisher's Note Springer Nature remains neutral with regard to jurisdictional claims in published maps and institutional affiliations. 